Gut, 1984, 25, 636-643

\title{
Gastrointestinal regulatory peptide storage granule abnormalities in jejunal mucosal diseases
}

\author{
J DAWSON, M G BRYANT, ${ }^{*}$ S R BLOOM, AND T J PETERS
}

From the Division of Clinical Cell Biology, MRC Clinical Research Centre, Harrow, Middlesex, and Department of Medicine, Royal Postgraduate Medical School, London

SUMmaRY The mucosal concentrations of seven regulatory peptides and the density properties and integrity of their storage granules have been studied in mucosal biopsies from the human jejunum in eight gastrointestinal disease states and compared with normal controls. In diseases with associated mucosal inflammation (coeliac disease, Crohn's disease with jejunal involvement, postinfective tropical malabsorption, and common variable immunodeficiency) there was a selective increase in fragility of the gastric inhibitory polypeptide (GIP) and somatostatin storage granules. The gastrin, motilin, enteroglucagon, secretin, and vasoactive intestinal polypeptide granules had normal properties in these conditions. In diseases in which diarrhoea occurred in the absence of changes in jejunal mucosal histology (irritable bowel syndrome, pancreatic insufficiency, jejuno-ileal bypass for morbid obesity, and purgative abuse) there were no abnormalities of the storage granules. Increased mucosal concentrations of all peptides except vasoactive intestinal polypeptide (VIP) were found in coeliac disease and selective increases of VIP found in Crohn's disease, motilin in the irritable bowel syndrome and gastrin and GIP in pancreatic insufficiency. It is suggested that the storage granule abnormalities in the diseases with abnormal mucosal histology are secondary to the inflammatory changes.

With the major exception of the gut hormone secreting tumours there is as yet little evidence that the gastrointestinal hormones are aetiologically important in gastrointestinal diseases in which they have been studied. Plasma studies, however, have shown marked abnormalities of basal regulatory peptide concentrations and release patterns in a variety of pathological conditions. ${ }^{1}$ Quantification of the mucosal endocrine cells ${ }^{2-4}$ and morphological studies of peptidergic nerves ${ }^{5}$ have also shown abnormalities of some peptides in a variety of gastrointestinal diseases. It might be expected, therefore, that some of these abnormalities will be reflected in altered mucosal concentrations of the peptides and altered properties of the storage granules. In this study we have investigated systematically the mucosal regulatory peptide storage granule properties, as determined by isopycnic sucrose density centrifugation, in the jejunum in conditions with a demonstrable morphological abnormality (coeliac disease, postinfective

Address for correspondence: Dr J Dawson, Department of Medicine, Queen Elizabeth Hospital, Edgbaston, Birmingham.

Received for publication 26 August 1983

* Deceased tropical malabsorption, Crohn's disease, and common variable immunodeficiency) and other conditions in which there is likely to be a functional small bowel abnormality (irritable bowel syndrome, purgative abuse, small bowel bypass, and pancreatic insufficiency). The storage granule properties in these conditions together with the mucosal peptide activities have been compared with normal controls.

\section{Methods}

PATIENTS

Jejunal biopsies were obtained from the following group of patients: 12 healthy volunteers with normal jejunal histology and no evidence of gastrointestinal disease; eight patients with untreated coeliac disease associated with subtotal villous atrophy; five patients with Crohn's disease affecting the jejunum in whom biopsies showed moderately severe inflammatory changes; three patients with postinfective tropical malabsorption in whom biopsies showed histological evidence of partial villous atrophy; six patients with common variable immunodeficiency associated with severe diarrhoea and partial villous atrophy; six patients who had undergone jejuno- 
ileal bypass surgery for morbid obesity - biopsies were taken seven to 15 months after operation from the functioning jejunum and showed no histological abnormality; three patients with purgative associated diarrhoea and no histological abnormality; six patients with the irritable bowel syndrome associated with diarrhoea and no histological abnormality; and six patients with diarrhoea and steatorrhoea associated with pancreatic insufficiency caused by alcoholic chronic pancreatitis and documented by secretin-pancreozymin or Lundh pancreatic stimulation tests. These studies were approved by the local ethical committees.

\section{TECHNIQUES}

Biopsies were obtained with a Crosby capsule from the jejunum, after a 12 hour fast, approximately 10 $\mathrm{cm}$ from the ligament of Treitz. The biopsies were divided, half being processed for routine histology and half, approximately $10 \mathrm{mg}$ wet weight, collected in $3 \mathrm{ml}$ of ice cold sucrose solution $(0.3 \mathrm{~mol} / \mathrm{l})$ containing $1 \mathrm{mmol} / \mathrm{l}$ disodium EDTA ( $\mathrm{pH} 7.4)$ and $22 \mathrm{mmol} / \mathrm{l}$ ethanol. The tissue was homogenised as previously described, ${ }^{6}$ and, after low speed centrifugation to remove nuclei and cell debris, the postnuclear supernatant was subjected to isopycnic sucrose density centrifugation ${ }^{6}$ in a Beaufay small volume automatic zonal rotor. ${ }^{7}$ Aliquots of the gradient fractions thus obtained were assayed using radioimmunoassays especially modified and optimised to the small quantities of tissue available $^{68}$ to detect gastrin, gastric inhibitory polypeptide (GIP), motilin, secretin, somatostatin, enteroglucagon, and vasoactive intestinal polypeptide (VIP). ${ }^{6-11}$ All homogenisation and fractionation procedures were performed at $0^{\circ} \mathrm{C}$ to minimise proteolytic degradation of hormones and immediately after fractionation aliquots of gradient fractions were mixed with an equal volume of $0 \cdot 2$ $\mathrm{mol} / \mathrm{l}$ hydrochloric acid to stabilise the peptides and the samples were deep frozen at $-20^{\circ} \mathrm{C}$ until radioimmunoassay of hormone content. Protein in the homogenate was assayed by the technique of Lowry ${ }^{12}$ and protein in the subcellular fractions were assayed by a micromodification ${ }^{13}$ of the fluorimetric technique of Hiraoka and Glick. ${ }^{14}$ Bovine serum albumin (Sigma, London) was used as standard. The protein and hormone distribution results were expressed as frequency/density histograms. All calculations, plots, and fractionation recoveries were performed by computer as described previously. ${ }^{7}$ Mucosal peptide concentrations in the disease states studied were compared with those in normal controls using Student's $t$ test, and the Mann-Whitney $U$ test for non-parametric data.

\section{Results}

The Table shows the mucosal peptide concentrations in the eight disease states studied in comparison with normal controls. Significantly raised concentrations of all the regulatory peptides except VIP were found in coeliac disease. In Crohn's disease involving the jejunum significantly increased concentrations of VIP were noted. In pancreatic insufficiency significant rises of GIP and gastrin were found. In the irritable bowel syndrome significantly increased concentrations of motilin were found. In view of the small numbers statistics were not applied to the patients with tropical malabsorption and purgative diarrhoea but inspection indicated that mucosal peptide levels were similar to the normal controls. Figures 1-8

Table Peptide hormones in the jejunal mucosa in gastrointestinal diseases associated with normal and abnormal jejunal histology

\begin{tabular}{|c|c|c|c|c|c|c|c|c|c|}
\hline & $\begin{array}{l}\text { Normal } \\
\text { controls }\end{array}$ & $\begin{array}{l}\text { Coeliac } \\
\text { disease }\end{array}$ & $\begin{array}{l}\text { Tropical } \\
\text { mal- } \\
\text { absorption }\end{array}$ & $\begin{array}{l}\text { Jejunal } \\
\text { Crohn's } \\
\text { disease }\end{array}$ & $\begin{array}{l}\text { Immuno- } \\
\text { deficiency }\end{array}$ & $\begin{array}{l}\text { Pancreatic } \\
\text { insuf- } \\
\text { ficiency }\end{array}$ & $\begin{array}{l}\text { Jejuno- } \\
\text { ileal } \\
\text { bypass }\end{array}$ & $\begin{array}{l}\text { Purgative } \\
\text { diarrhoea }\end{array}$ & $\begin{array}{l}\text { Irritable } \\
\text { bowel }\end{array}$ \\
\hline Number & 12 & 8 & 3 & 5 & 6 & 6 & 6 & 3 & 6 \\
\hline Somatostatin & $9 \cdot 4 \pm 1 \cdot 6$ & $16 \cdot 3 \pm 1 \cdot 9+$ & $10 \cdot 3 \pm 1 \cdot 7$ & $10 \cdot 9 \pm 0 \cdot 9$ & $9 \cdot 4 \pm 1 \cdot 6$ & $8 \cdot 7 \pm 1 \cdot 3$ & $10 \cdot 2 \pm 1 \cdot 3$ & $10 \cdot 2 \pm 1 \cdot 2$ & $7 \cdot 8 \pm 1 \cdot 2$ \\
\hline $\begin{array}{l}\text { Gastric inhibitory } \\
\text { peptide (GIP) }\end{array}$ & $2 \cdot 5 \pm 0 \cdot 4$ & $4 \cdot 8 \pm 0 \cdot 2 \ddagger$ & $2 \cdot 9 \pm 0 \cdot 7$ & $1 \cdot 7 \pm 0 \cdot 4$ & $2 \cdot 5 \pm 0 \cdot 4$ & $6 \cdot 1 \pm 0 \cdot 5 \S$ & $3 \cdot 1 \pm 0 \cdot 4$ & $2 \cdot 8 \pm 0 \cdot 8$ & $2 \cdot 1 \pm 0 \cdot 3$ \\
\hline Gastrin & $2 \cdot 6 \pm 0 \cdot 4$ & $5 \cdot 9 \pm 1 \cdot 0 \ddagger$ & $2 \cdot 2 \pm 0 \cdot 5$ & $2 \cdot 1 \pm 0 \cdot 5$ & $2 \cdot 6 \pm 0 \cdot 4$ & $5 \cdot 7 \pm 0 \cdot 4 \S$ & $2 \cdot 4 \pm 0 \cdot 5$ & $2 \cdot 8 \pm 0 \cdot 3$ & $1 \cdot 7 \pm 0 \cdot 2$ \\
\hline Secretin & $3 \cdot 1 \pm 0 \cdot 6$ & $10 \cdot 2 \pm 2 \cdot 1 \S$ & $4 \cdot 3 \pm 1 \cdot 1$ & $2 \cdot 4 \pm 0 \cdot 5$ & $3 \cdot 1 \pm 0 \cdot 6$ & $3 \cdot 3 \pm 1 \cdot 1$ & $2 \cdot 0 \pm 0 \cdot 5$ & $2 \cdot 8 \pm 0 \cdot 8$ & $1.9 \pm 0.9$ \\
\hline Motilin & $3 \cdot 9 \pm 0 \cdot 7$ & $9 \cdot 0 \pm 0 \cdot 4 \ddagger$ & $5 \cdot 1 \pm 1 \cdot 8$ & $2 \cdot 7 \pm 0 \cdot 2$ & $3 \cdot 9 \pm 0 \cdot 7$ & $3 \cdot 7 \pm 0 \cdot 4$ & $4 \cdot 1 \pm 0 \cdot 3$ & $4 \cdot 1 \pm 0 \cdot 6$ & $7 \cdot 4 \pm 0 \cdot 8 \ddagger$ \\
\hline Enteroglucagon & $0 \cdot 6 \pm 0 \cdot 2$ & $0.9 \pm 0 \cdot 2^{*}$ & $0 \cdot 6 \pm 0 \cdot 3$ & $0 \cdot 5 \pm 0 \cdot 3$ & $0 \cdot 6 \pm 0 \cdot 2$ & $0 \cdot 5 \pm 0 \cdot 2$ & $0 \cdot 5 \pm 0 \cdot 1$ & $0 \cdot 4 \pm 0 \cdot 2$ & $0 \cdot 3 \pm 0 \cdot 2$ \\
\hline
\end{tabular}

Mucosal concentrations expressed as $\mathrm{pmol} / \mathrm{mg}$ protein.

Statistical significance from normal: ${ }^{*} \mathrm{p}<0 \cdot 05, \dagger p<0 \cdot 02, \ddagger \mathrm{p}<0 \cdot 01, \S \mathrm{p}<0 \cdot 001$. 
show the sucrose density gradient distributions of the seven regulatory peptides studied in the jejunum from patients with disease states in comparison with normal controls. The protein distributions were also recorded. The most striking change is noted in coeliac disease (Fig. 1) in which there is a selective increase in the soluble activity of GIP and somato-

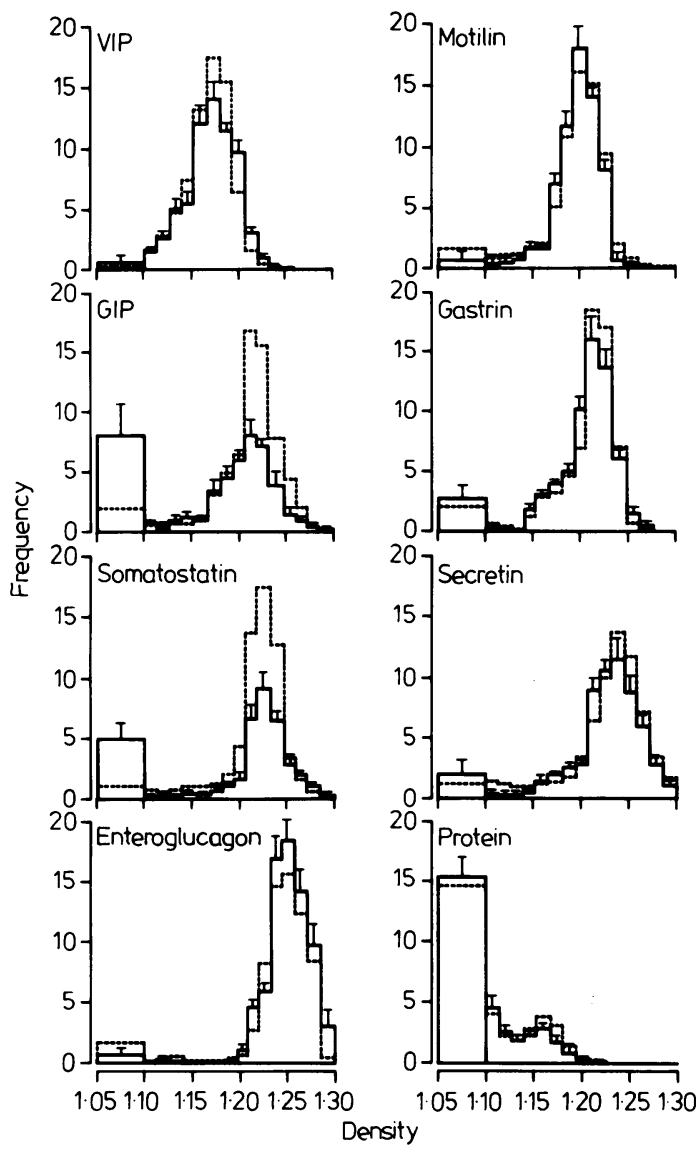

Fig. 1 Isopycnic centrifugation of postnuclear supernant from jejunal biopsy homogenate in untreated coeliac disease (solid line) in comparison with normal controls (dotted line). Graphs show frequency/density histograms for seven peptides and protein and represent averaged data from eight patients and six controls. Frequency (mean $\pm S D$ ) is defined as fraction of total recovered activity present in individual fractions divided by density span covered by that fraction. Activity present over density span 1.05-1.10 represents over arbitrary abscissa interval peptide remaining in sample layer and presumed to reflect soluble activity. Percentage recoveries for patients (mean $\pm S D$ ): VIP $89 \pm 12$, motilin $103 \pm 12$, GIP $94 \pm 17$, gastrin $97 \pm 13$, somatostatin $101 \pm 12$, secretin $91 \pm 9$, enteroglucagon $89 \pm 18$, protein $88 \pm 19$. statin. A similar but less marked selective increase in the soluable fractions of GIP and somatostatin was seen in tropical malabsorption (Fiḡ. 2) and Crohn's disease (Fig. 3) and an increase in soluble GIP in common variable immunodeficiency (Fig. 4). It was noted that in all these patients active mucosal inflammation was present. The remaining five

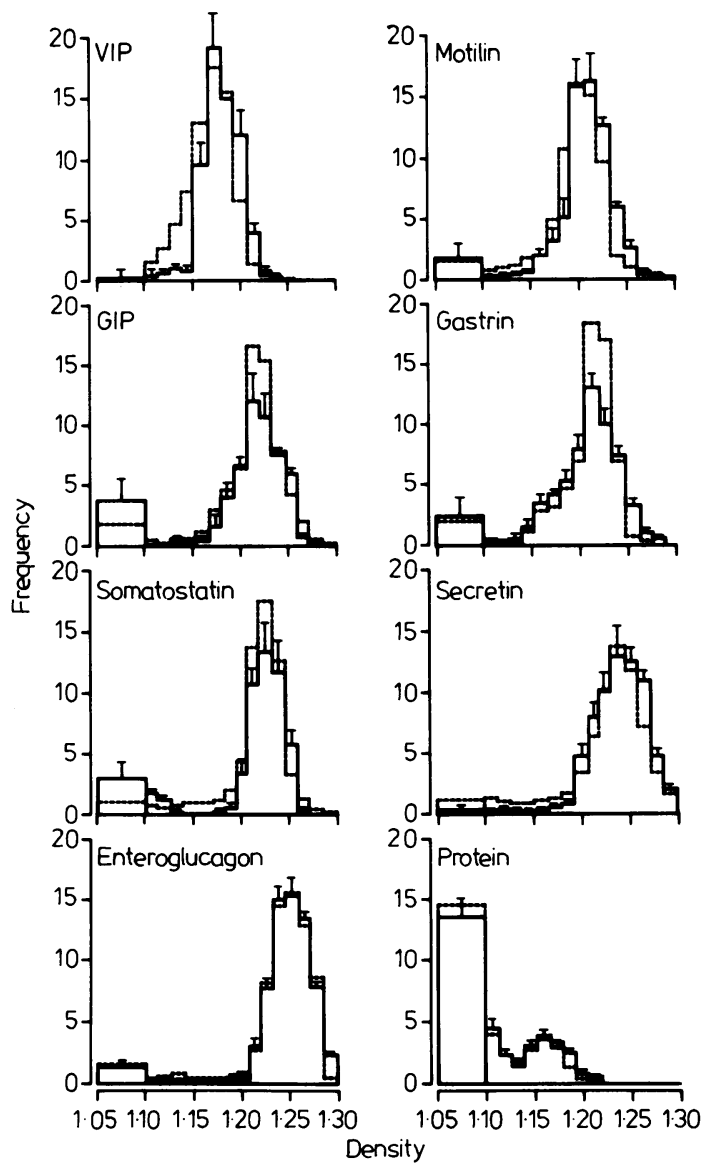

Fig. 2 Isopycnic centrifugation of postnuclear supernant from jejunal biopsy homogenate averaged from three patients with postinfective tropical malabsorption (solid line) in comparison with six normal controls (dotted line). For details see legend to Fig. 1 . Percentage recoveries for patients (mean $\pm S D$ ): VIP 92 \pm 19 , motilin 101 \pm 13, GIP $88 \pm 20$, gastrin $99 \pm 10$, somatostatin $94 \pm 12$, secretin $87 \pm 21$, enteroglucagon $103 \pm 19$, protein $89 \pm 13$. 
peptides, VIP, motilin, gastrin, secretin, and enteroglucagon, showed no increase in soluble activity, with the exception of a modest increase in soluble VIP in Crohn's disease. None of the peptides studied showed any change in the density gradient distribution in diseases associated with inflammation and each retained its characteristic modal density. This indicates that the granules which remained intact have normal density properties. In patients with pancreatic insufficiency (Fig. 5), jejuno-ileal

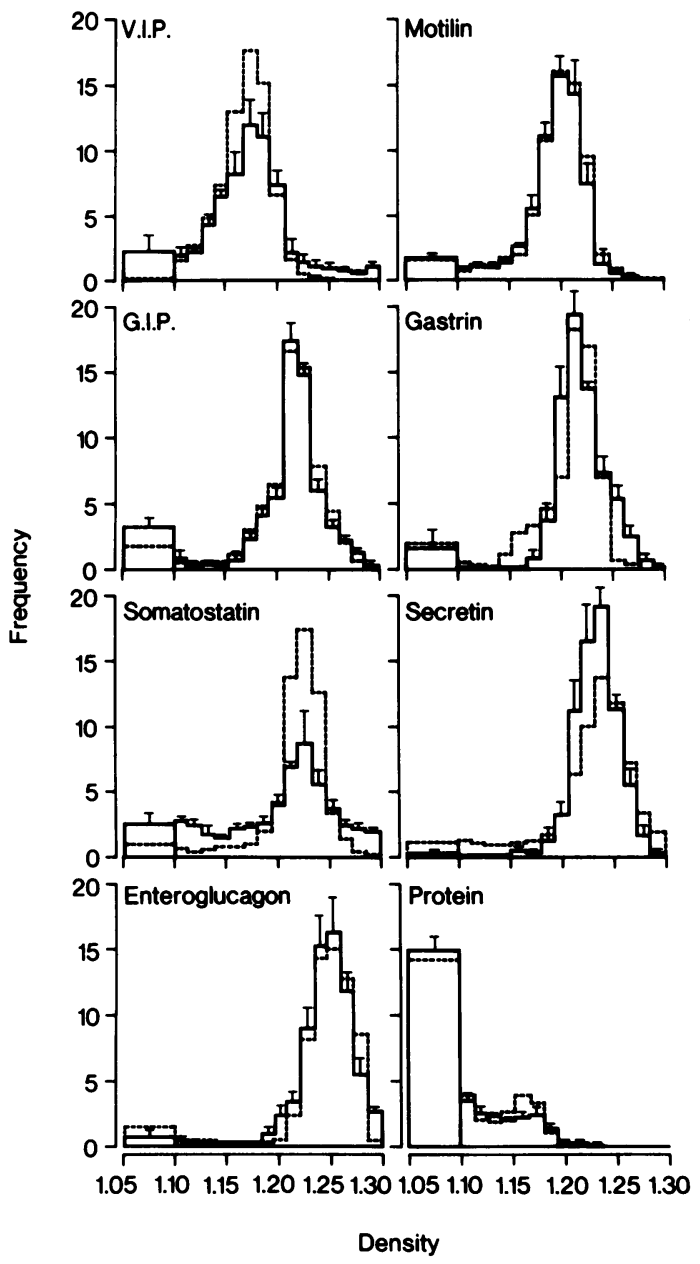

Fig. 3 Isopycnic centrifugation of postnuclear supernant from jejunal biopsy homogenate averaged from five patients with jejunal Crohn's disease (solid line) in comparison with six normal controls (dotted line). For details see legend to Fig. 1. Percentage recoveries for patients (mean $\pm S D)$ : VIP $102 \pm 12$, motilin $89 \pm 14$, GIP $89 \pm 17$, gastrin $96 \pm 13$, somatostatin $98 \pm 14$, secretin $107 \pm 12$, enteroglucagon $101 \pm 13$, protein $89 \pm 12$. bypass (Fig. 6), purgative associated diarrhoea (Fig. 7), and irritable bowel syndrome (Fig. 8) there was no change in the density properties of the secretory granules and no marked changes in soluble activity. It was noted that all these patients had normal jejunal histology.

\section{Discussion}

This is the first study in which the properties of the

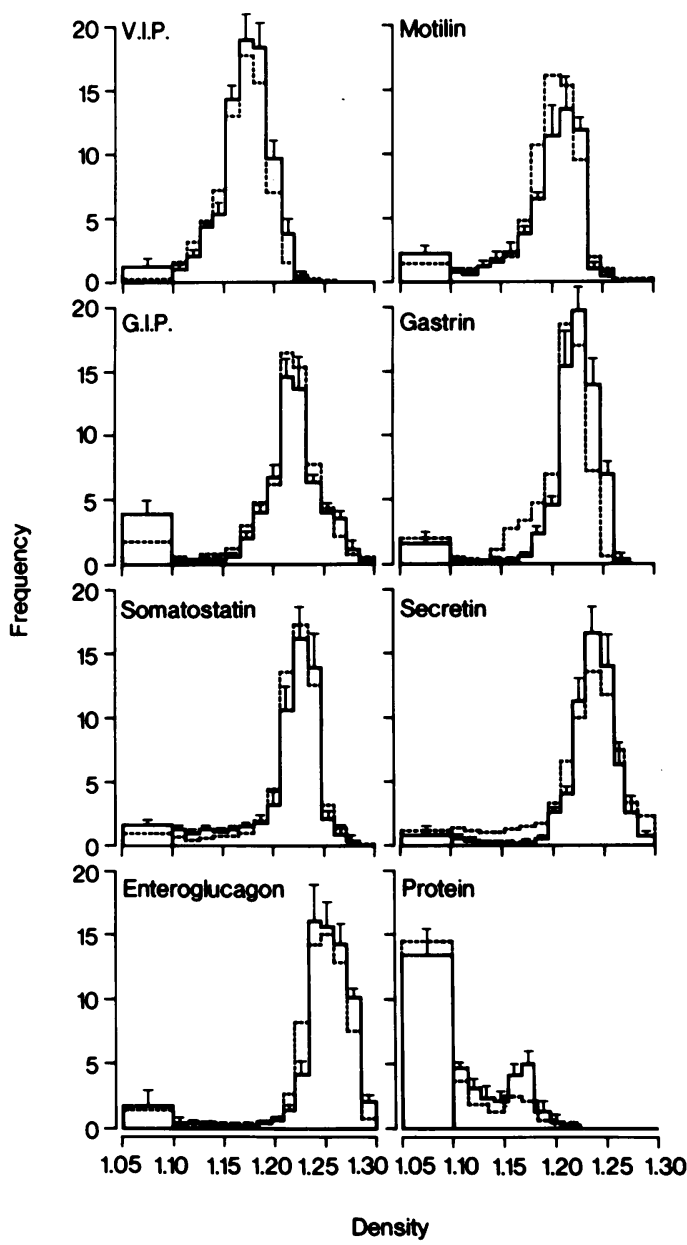

Fig. 4 Isopycnic centrifugation of postnuclear supernant from jejunal biopsy homogenate averaged from six patients with common variable immunodeficiency (solid line) in comparison with six normal controls (dotted line). For details see legend to Fig. 1. Percentage recoveries for patients (mean $\pm S D): V I P 89 \pm 12$, motilin $97 \pm 13$, GIP $89 \pm 14$, gastrin $103 \pm 19$, somatostatin $99 \pm 6$, secretin $87 \pm 19$, enteroglucagon $89 \pm 12$, protein $94 \pm 17$. 
mucosal regulatory peptide secretory granules and the concentrations of the peptides have been systematically investigated in the human jejunum in a wide range of disease states. The sucrose density gradient experiments indicate a selective increase in the soluble fraction of somatostatin and gastric inhibitory peptide in the four diseases in which diarrhoea is associated with histological jejunal abnormalities. This suggests a selective increase in fragility of the storage granules of these two

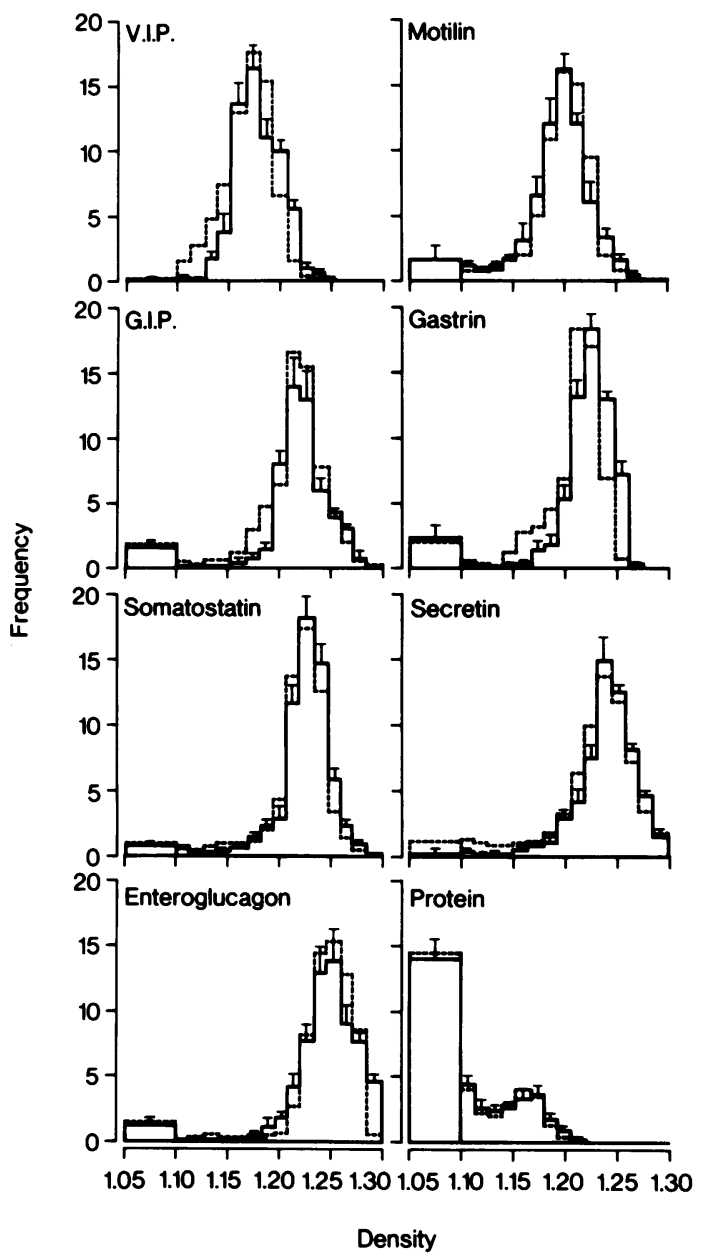

Fig. 5 Isopycnic centrifugation of postnuclear supernant from jejunal biopsy homogenate averaged from six patients with pancreatic insufficiency (solid line) in comparison with six normal controls (dotted line). For details see legend to Fig. 1. Percentage recoveries for patients (mean $\pm S D$ ):

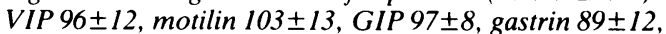
somatostatin $88 \pm 19$, secretin $97 \pm 12$, enteroglucagon $104 \pm 13$, protein $91 \pm 15$. peptides. ${ }^{15}$ The changes are most marked in coeliac disease where the inflammatory changes are greatest and less marked in tropical malabsorption, Crohn's disease, and common variable immunodeficiency. The pattern of the peptide hormone secretory granule abnormalities does not correlate with the abnormal plasma peptide release reported in these syndromes. Thus in coeliac disease there is a failure of release of GIP and secretin, increased release of enteroglucagon and no change in gastrin release in

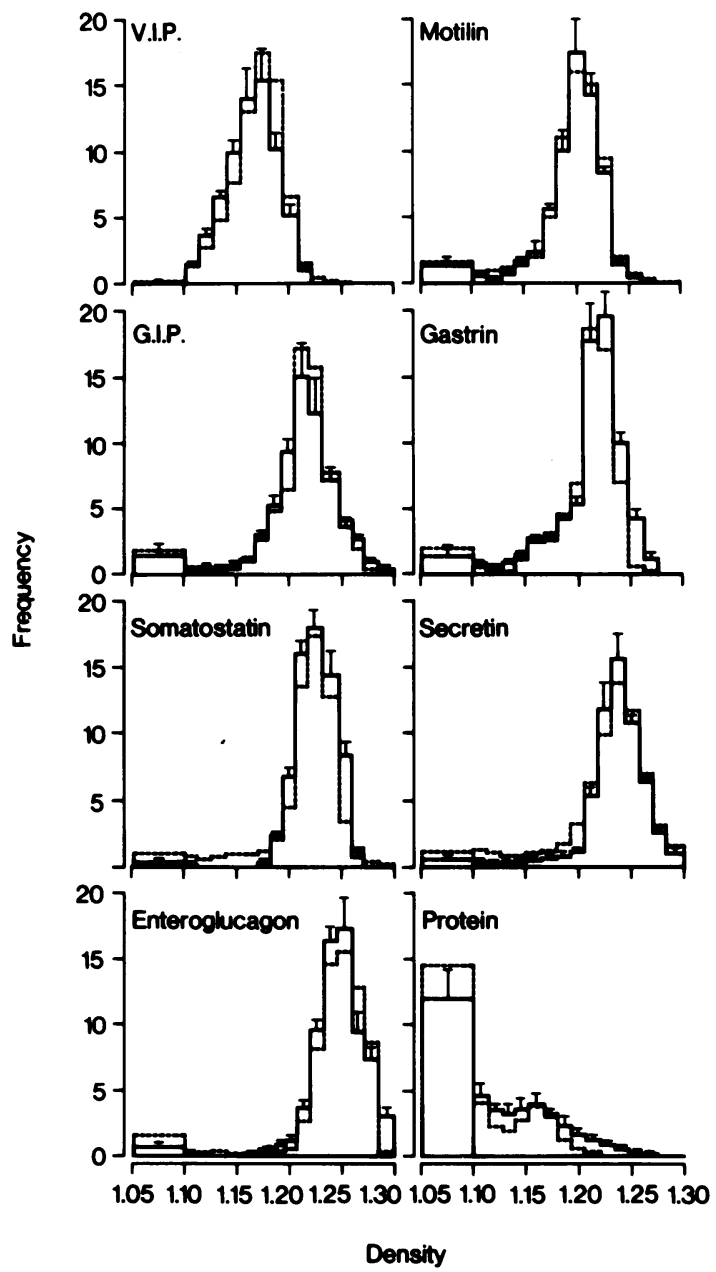

Fig. 6 Isopycnic centrifugation of postnuclear supernant from jejunal biopsy homogenate averaged from six jejunoileal bypass patients (solid line) in comparison with six normal controls (dotted line). For details see legend to Fig. 1. Percentage recoveries for patients (mean $\pm S D$ ): VIP $87 \pm 12$, motilin $94 \pm 19$, GIP $89 \pm 14$, gastrin 104 \pm 12 , somatostatin $101 \pm 17$, secretin $79 \pm 18$, enteroglucagon $91 \pm 12$, protein $94 \pm 18$. 
response to intraluminal stimuli, ${ }^{16} 17$ while the secretory granule abnormalities in the present study are confined to somatostatin and GIP. Similarly, in tropical malabsorption ${ }^{18}$ and Crohn's disease ${ }^{19}$ the characteristically abnormal pattern of peptide release does not reflect the secretory granule abnormalities shown. Furthermore, while a different pattern of abnormality is found in each of these disease states, the secretory granule abnormality is common to all. This, together with

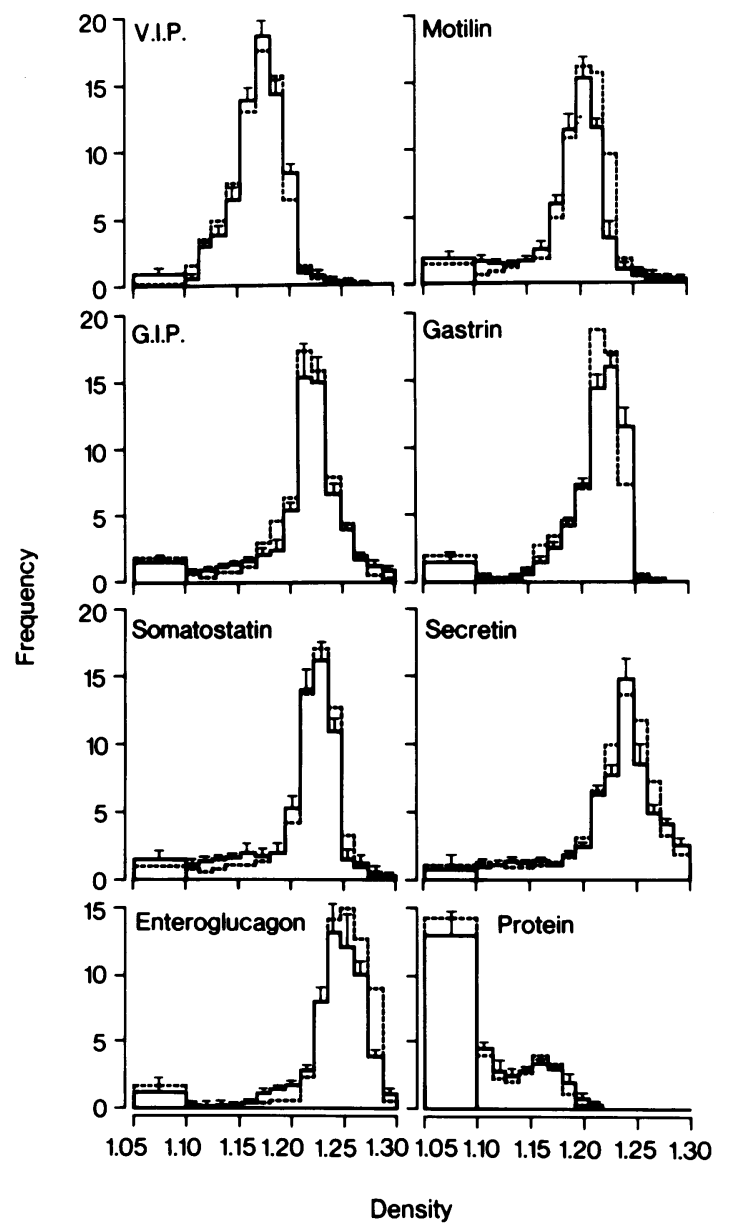

Fig. 7 Isopycnic centrifugation of postnuclear supernant from jejunal biopsy homogenate averaged from three patients with purgative associated diarrhoea (solid line) in comparison with six normal controls (dotted line). For details see legend to Fig. 1. Percentage recoveries for patients (mean $\pm S D$ ): VIP 94 \pm 12 , motilin $97 \pm 19$, GIP $102 \pm 15$, gastrin $104 \pm 12$, somatostatin $97 \pm 12$, secretin $89 \pm 15$, enteroglucagon $101 \pm 12$, protein $93 \pm 8$. the exclusive association of the secretory granule abnormalities with inflammatory diseases, suggests that the granule changes are most likely to be secondary to the final histological insult. The exact mechanism of the secondary changes is uncertain but increased fragility of both lysosomes and brush borders have been noted in coeliac disease ${ }^{15}$ and tropical malabsorption. ${ }^{20}$ Further it has been argued that the lysosomal abnormalities may be implicated in the enterocyte damage in coeliac disease. ${ }^{15}$ It is

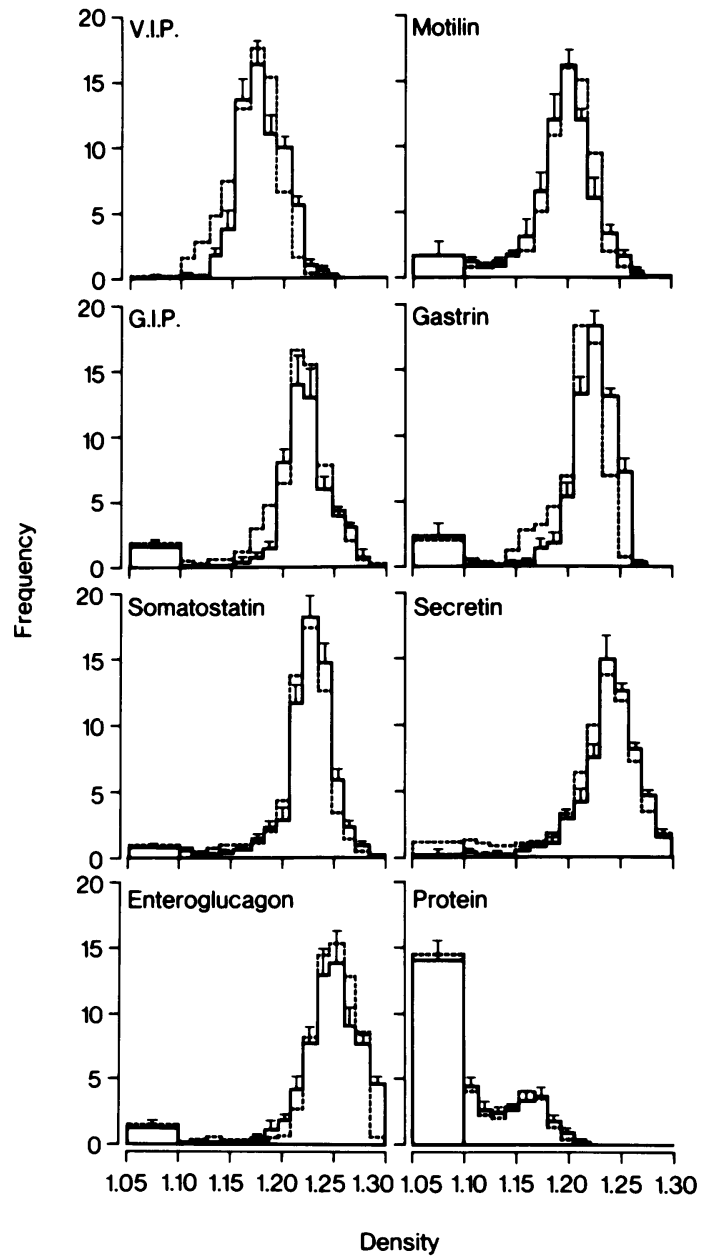

Fig. 8 Isopycnic centrifugation of postnuclear supernant from jejunal biopsy homogenate averaged from six patients with irritable bowel syndrome (solid line) in comparison with six normal controls (dotted line). For details see legend to Fig. 1. Percentage recoveries for patients (mean $\pm S D$ ): VIP $87 \pm 12$, motilin 101 \pm 6, GIP $89 \pm 15$, gastrin $94 \pm 12$, somatostatin $101 \pm 13$, secretin $102 \pm 8$, enteroglucagon $96 \pm 17$, protein $93 \pm 12$. 
possible therefore that such lysosomal changes may affect the endocrine cells and that the GIP and somatostatin granules are particularly susceptible to damage.

The abnormalities in mucosal peptide concentrations, although in some instances marked, must be interpreted with more caution. In coeliac disease the well documented failure of release of upper small bowel peptides into the plasma ${ }^{16} 1721$ raises the possibility that the high mucosal concentrations found in this study result from an accumulation of peptides in the coeliac mucosa. The gross distortion of mucosal architecture, oedema, and inflammatory changes, however, may produce artificial changes in mucosal peptide concentrations when expressed in terms of protein content. Thus it would be premature to draw firm conclusions. The results do, however, accord with the morphological and immunocytochemical studies which show a generalised hyperplasia of gut endocrine cells ${ }^{2}{ }^{4}$ in adult coeliac mucosa. Similarly, in Crohn's disease the increased mucosal VIP correlates well with abnormalities of the innervation of the bowel wall, ${ }^{22}$ particularly the VIP innervation. ${ }^{523}$ Although the current studies do not shed further light on the mechanism of the abnormal peptidergic innervation, the sucrose density gradient experiments do indicate that, despite the gross abnormalities of the neurones, the secretory granules themselves have normal properties.

The increased mucosal concentration of motilin in the irritable bowel syndrome and gastrin and GIP in pancreatic insufficiency likewise do not correlate with the plasma abnormalities reported in these conditions. ${ }^{24-26}$ Motilin, however, is known to be concerned with gastrointestinal motility ${ }^{27} 28$ and the increased mucosal concentrations observed in the irritable bowel syndrome may reflect intramucosal paracrine processes which could be concerned with the pathogenesis of this syndrome. The mucosal peptide changes in chronic pancreatitis are not readily explained. Histochemical studies have shown increased numbers of GIP but not gastrin cells in this condition. ${ }^{3}$ It has also been reported that experimental pancreatic duct ligation is associated with secondary changes in the small bowel epithelial cells ${ }^{29}$ it is thus possible that the observations in this condition are a secondary morphological phenomenon with no functional sequelae.

In conclusion, these studies give no support to hypotheses that the regulatory peptides studied are aetiologically important in the disease states investigated. They do, however, provide important new insights to the properties of the secretory granules, in particular indicating that the GIP and somatostatin granules differ in some way from other granules being more susceptible to damage by mucosal inflammation. The mechanism of this damage and the reason for the differential susceptibility of these two secretory granules merit further study.

The authors wish to thank the many clinicians who allowed their patients to be studied for this project. In particular we are grateful to Drs V S Chadwick, A J Levi, and A M Tomkins. We are also grateful for the help of Mrs D Campbell who typed the manuscript and for the financial support of the Medical Research Council.

\section{References}

1 Bloom SR, Polak JM. Plasma hormone concentrations in gastrointestinal disease. Clin Gastroenterol 1980; 9: 785-97.

2 Polak JM, Pearse AGE, Von Noorden S et al. Secretin cells in coeliac disease. Gut 1973; 14: 870-4.

3 Polak JM, Bloom SR, McCrossan MV et al. Abnormalities of endocrine cells in patients with duodenal ulceration (DU) and with chronic pancreatitis. Gastroenterology 1977; 72: 822.

4 Sjolund K, Alumets J, Berg N-O et al. Duodenal endocrine cells in adults coeliac disease. Gut 1979; 20: 547-22.

5 Bishop AE, Polak JM, Bryant MG et al. Abnormalities of vasoactive intestinal polypeptide-containing nerves in Crohn's disease. Gastroenterology 1980; 79: 853-60.

6 Dawson J, Bryant MG, Bloom SR et al. Subcellular fractionation studies of human gastric antrum: localisation of the mucosal peptide hormones. Clin Sci 1980; 59: $1-6$.

7 Peters TJ. Analytical subcellular fractionation of jejunal biopsy specimens methodology and characterisation of the organelles in normal tissues. Clin Sci Mol Med 1976; 51: 557-74.

8 Bryant MG, Dawson J, Bloom SR et al. Separation of the gut-hormone endocrine-cell storage granules of human jejunum using analytical subcellular fractionation. Gut 1980; 21: 177-80.

9 Adrian TE, Barnes AJ, Long RG et al. The effect of somatostatin analogs on secretion of growth, pancreatic and gastrointestinal hormones in man. $J$ Clin Endocr Metab 1981; 53: 675-81.

10 Bryant MG, Bloom SR. Distribution of the gut hormones in the primate intestinal tract. Gut 1979; 20: 653-9.

11 Ghatei MA, Bloom SR. In: Bloom SR, Polak JM, eds. Enteroglucagon in man. Edinburgh: Churchill Livingstone, 1981: 332-8.

12 Lowry $\mathrm{OH}$, Rosebrough NJ, Farr $\mathrm{AL}$ et al. Protein measurement with folin-phenol reagent. J Biol Chem 1951; 224: 1047-64.

13 Peters TJ, Batt RM, Heath JR et al. The microassay of intestinal disaccharidases. Biochem Med 1976; 15: 146-8. 
14 Hiraoka T, Glick D. Studies in histochemistry LXXI. Measurement of protein in millimicrogram amounts by quenching of dye fluorescence. Anal Biochem 1963; 5: 497-504.

15 Peters TJ, Heath JR, Wansborough-Jones MH et al. Enzyme activities and properties of lysosomes and brush-borders in jejunal biopsies from control subjects and patients with coeliac disease. Clin Sci Mol Med 1975; 48: 259-67.

16 Rhodes RA, Tai HH, Chey WY. Impairment of secretin release in coeliac sprue. Dig Dis 1978; 23: 833-9.

17 Besterman HS, Bloom SR. Sarson DL et al. Gut hormone profile in coeliac disease. Lancet 1978; 1: $785-8$.

18 Besterman HS, Cook GC, Sarson DL et al. Gut hormones in tropical malabsorption. Br Med J 1979; 1: 1252-5.

19 Besterman HS, Bloom SR, Christofides ND et al. Gut hormone profile in inflammatory bowel disease. [Abstract] Gut 1978; 19: A988.

20 Peters TJ, Jones P, Wells G et al. Sequential enzyme and subcellular fractionation studies on jejunal biopsy specimens from patients with post-infective tropical malabsorption. Clin Sci 1979; 56: 479-86.

21 O'Connor FA, McLoughlin JC, Buchanan KD. Impaired immunoreactive secretin release in coeliac disease. Br Med J 1977; 1: 811-2.

22 Davis DR, Dockerty MB, Mayo CW. Myenteric plexus in regional enteritis: study of the number of ganglion cells in ileum in 24 cases. Surg Gynecol Obstet 1955; 101: 208-16.

23 O'Morain C, Bishop AE, Polak JM et al. VIP nerves in endoscopic rectal biopsies from patients with inflammatory bowel disease: a double blind study. [Abstract] Gut 1981; 22: A440.

24 Georghegan J, Fielding JF. Serum gastrin and the irritable bowel syndrome. Irish J Med Sci 1978; 147: 156.

25 Besterman JS, Sarson DL, Rambaud JC et al. Gut hormone responses in the irritable bowel syndrome. Digestion 1981; 21: 219-24.

26 Besterman JS, Adrian TE, Christofides ND et al. Gut hormone profile in pancreatic disease. [Abstract] Gut 1978; 19: A444-5.

27 Van-Trappen G, Janssens J, Peeters TL et al. Motilin and the interdigestive migrating motor complex in man. Dig Dis Sci 1979; 24: 479-500.

28 Rennie JA, Christofides ND, Mitchenere $\mathrm{P}$ et al. Motilin and human colonic activity. Gastroenterology 1980; 78: 1243 .

29 Balas D. Senegas-Balas F, Bertrand C et al. Effects of pancreatic duct ligation on the hamster intestinal mucosa. Digestion 1980; 20: 157-67. 